\title{
Phytophagy of the predator Podisus nigrispinus (Dallas, 1851) (Hemiptera: Pentatomidae) fed on prey and Brassicaceae
}

\author{
J. F. J. Grigollia*, M. M. Kubota Grigolli ${ }^{b}$, D. G. Ramalho ${ }^{c}$, A. L. Martins ${ }^{\text {, }}$, \\ A. M. Vacari ${ }^{b}$ and S. A. De Bortoli ${ }^{b}$ \\ ${ }^{a}$ Fundação MS, CP 137, CEP 79150-000, Maracaju, MS, Brazil \\ 'Faculdade de Ciências Agrárias e Veterinárias - FCAV, Universidade Estadual Paulista - UNESP, \\ Via de Acesso Prof. Paulo Donato Castellane, s/n, CEP 14884-900, Jaboticabal, SP, Brazil \\ ${ }^{c}$ Faculdade de Filosofia, Ciências e Letras de Ribeirão Preto - FFCLRP, Universidade de São Paulo - USP, \\ Avenida Bandeirantes, 3900, Monte Alegre, CEP 14040-901, Ribeirão Preto, SP, Brazil \\ dUniversidade Federal do Paraná - UFPR, CP 19020, CEP 81531-980, Curitiba, PR, Brazil \\ *e-mail: fernando@fundacaoms.org.br
}

Received: October 8, 2015 -Accepted: May 16, 2016 - Distributed: November 31, 2017

\begin{abstract}
The purpose of this study was to investigate the development and reproduction of the zoophytophagous predator Podisus nigrispinus (Dallas) (Heteroptera: Pentatomidae) fed kale, broccoli and cabbage affects its. Nymphs and adults of this predator were fed on larvae of Plutella xylostella (L.) (Lepidoptera: Plutellidae) as prey with kale, cabbage, or broccoli. In the nymph period, the duration and prey consumption were similar with all the Brassicacea cultivar. However, nymph viability was higher for predators with broccoli leaves. The mean weight of $5^{\text {th }}$-instar nymphs, newly emerged females and the sex ratio were similar among the Brassicacea cultivars, while newly emerged males were heavier with kale and broccoli leaves. The supply of broccoli leaves resulted in greater oviposition, higher number of eggs per egg mass and longer longevity of $P$. nigrispinus males and females. Furthermore, the consumption of $P$. xylostella larvae by adult predators was higher with these cultivars. The net reproductive rate $\left(\mathrm{R}_{0}\right)$ and mean generation time $(\mathrm{T})$ were highest for predators with prey and broccoli leaves. The reproductive parameters of $P$. nigrispinus were enhanced when fed on P. xylostella larvae with and broccoli leaves, which can be an alternative diet in laboratory rearing of this predator.
\end{abstract}

Keywords: biological control, mass rearing, predatory stinkbug, zoophytophagous.

\section{Fitofagia do predador Podisus nigrispinus (Dallas, 1851) (Hemiptera: Pentatomidae) em diferentes brassicáceas}

\section{Resumo}

O objetivo deste estudo foi verificar o desenvolvimento e reprodução do zoofitófago Podisus nigrispinus (Dallas) (Heteroptera: Pentatomidae) em couve, brócolis e repolho. Ninfas e adultos deste predador foram alimentados com lagartas de Plutella xylostella (L.) (Lepidoptera: Plutellidae) como presa e receberam folhas de couve, repolho ou brócolis. Durante o período ninfal, a duração do período e o consumo de presas foram semelhantes com as diferentes cultivares de brassicácea. Porém, a viabilidade ninfal foi maior para predadores com folhas de brócolis. O peso de ninfas de quinto instar e de fêmeas recém-emergidas e a razão sexual de $P$. nigrispinus foram semelhantes entre as cultivares de brassicáceas, enquanto que o peso de machos recém-emergidos foi maior com folhas de couve e brócolis. Folhas de brócolis proporcionaram maiores número de oviposições, ovos por postura e longevidade de machos e fêmeas de P. nigrispinus. Além disso, o consumo de lagartas de P. xylostella por adultos desse predador fora maiores com esta cultivar. A taxa líquida de reprodução $\left(\mathrm{R}_{0}\right)$ e o tempo médio de geração $(\mathrm{T})$ foram maiores para predadores com presa e folhas de brócolis. Podisus nigrispinus alimentados com lagartas de P. xylostella e folhas de brócolis apresentaram melhores parâmetros reprodutivos, podendo ser uma alternativa para a criação deste predador em laboratório.

Palavras-chave: controle biológico, criação massal, percevejo predador, zoofitófago.

\section{Introduction}

Podisus nigrispinus (Dallas, 1851) (Hemiptera: Pentatomidae) is an important biological control agent in several crops (Medeiros et al., 2000). It can be found in
Central and South America (Thomas, 1992), especially in the Neotropics (De Clercq, 2000). In Brazil, P. nigrispinus was reported in several States, e.g., Espírito Santo, 
Maranhão, Minas Gerais, Mato Grosso do Sul, Pará, and São Paulo (Oliveira et al., 2011). Podisus species have a generalist feeding habit, but mainly on lepidopteran larvae (Oliveira et al., 2004a).

Due to the ease of rearing this stinkbug in the laboratory, these insects are produced and released in biological control programs of defoliating larvae (Zanuncio et al., 2002). Alternative preys and artificial diets are used to mass rearing this predator $P$. nigrispinus (Fernandes et al., 1996; Zanuncio et al., 1996a; Saavedra et al., 1997; Zanuncio et al., 1996b), in view of the difficulties of using natural prey in the laboratory.

The prey availability and quality can influence the development of P. nigrispinus (Valicente and O'Neil 1993; De Clercq et al., 1998; Molina-Rugama et al., 1998a; Mourão et al., 2003). However, this predator can also feed on plants without damaging them (Naranjo and Stimac, 1985; Ruberson et al., 1986; Naranjo and Stimac, 1987; De Clercq and Degheele, 1992; Lemos et al., 2001). This feeding behavior allows the classification of the insect as zoophytophagous (Coll and Guershon, 2002; Azevedo et al., 2007), since the combined use of plants and prey can improve their biological characteristics (Lemos et al., 2001; Oliveira et al., 2002).

There are at least three hypotheses to explain the zoophytophagous habit in predators: (1) equivalence - plants can provide nutrients when prey is absent or scarce; (2) facilitation - plants provides essential nutrients complementary to predation; and (3) independence - plant material provides essential nutrients absent in the prey (Lalonde et al., 1999; Eubanks and Denno, 2000; Gillespie and McGregor, 2000; Sinia et al., 2004).

Dietary habits can change the life cycle of insects, since well-fed individuals reproduce more and more frequently (Lenski, 1984; Molina-Rugama et al., 1997; Chapman, 1998; Molina-Rugama et al., 1998b; Lemos et al., 2001). The objective of this study was to evaluate the development and reproduction of P. nigrispinus in three different Brassicacea cultivars to improve laboratory rearing of this predator.

\section{Material and Methods}

The experiment was carried out in the Laboratory of Biology and Rearing of Insects (LBCI) of the Department of Plant Protection, FCAV/UNESP, in Jaboticabal, São Paulo, Brazil in an air-conditioned room at $25 \pm 1{ }^{\circ} \mathrm{C}$, relative humidity of $70 \pm 10 \%$ and 12 -hour photoperiod ( $12 \mathrm{~h}$ light and 12 hours dark). The treatments consisted of three Brassicacea species: kale Brassica oleracea var. acephala (kales 'Manteiga' hybrid HS-20), cabbage Brassica oleracea var. capitata (cabbage 'Bob Cat') and broccoli Brassica oleracea var. italic (broccoli 'Piracicaba'). In the tests, the predatory stinkbug P. nigrispinus was fed ad libitum on prey Plutella xylostella (L.) (Lepidoptera: Plutellidae) larvae. The mass-reared insects used in the experiment were from the LBCI, FCAV/UNESP, Jaboticabal, São Paulo, Brazil.

\subsection{Biological parameters of Podisus nigrispinus nymphs feeding on Plutella xylostella larvae as prey and Brassicaceae}

A completely randomized design with six replications was used to evaluate $P$. nigrispinus nymph stage. Transparent plastic cylindrical $1000 \mathrm{~mL}$ containers (diameter $15 \mathrm{~cm}$, height $10 \mathrm{~cm}$ ), covered with plastic lid were used. Two tubes $\left(1.5 \mathrm{~cm}^{3}\right)$ were fixed to the lid, one to provide water and the other to fix a Brassicacea (cabbage, kales or broccoli) leaf.

Each container represented one replication, in which 10 predatory second-instar P. nigrispinus nymphs $(<24 \mathrm{~h}$ old $)$ were placed, which were initially fed with 20 fourth-instar $P$. xylostella larvae and a leaf of one of the Brassicaceae. As the nymphs developed, the number of larvae available increased, avoiding lack of prey, as well as cannibalism. The sterilization of the containers and exchange of water, leaves and containers, as well as evaluations were performed every 48 hours.

The following biological parameters were evaluated in the nymph stage: duration of each stage, duration of the nymph stage, nymph viability and nymph consumption. In addition, 10 to $24 \mathrm{~h}$-old $5^{\text {th }}$ - instar nymphs were weighed per treatment.

\subsection{Biological parameters of Podisus nigrispinus} adults feeding on Plutella xylostella larvae as prey and Brassicaceae

After adult emergence, 10 pairs were formed per treatment, and one couple per container was placed in a transparent $1000 \mathrm{~mL}$ plastic container (diameter $15 \mathrm{~cm}$, height $10 \mathrm{~cm}$ ), and covered with a plastic lid. Two tubes $\left(1.5 \mathrm{~cm}^{3}\right)$ were fixed to the lid, one to provide water and the other to fix a Brassicacea (cabbage, kales or broccoli) leaf. Per container, 50 fifth instar $P$. xylostella larvae were offered as prey. The experimental design used was completely randomized with three treatments (kales, cabbage, and broccoli) and 10 replications.

The following biological characteristics were evaluated: weight of newly emerged males and females ( $<24 \mathrm{~h}$ old $)$, longevity of males and females, oviposition period, and total daily number of eggs per female, egg viability and egg incubation period.

\subsection{Fertility life table of Podisus nigrispinus}

The biological parameters of P. nigrispinus determined in three different Brassicaceae were used to establish a life fertility table (Birch, 1948; Silveira Neto et al., 1976; Price, 1984).

From the values of age ranges (x), specific fertility $\left(\mathrm{m}_{\mathrm{x}}\right)$ and survival probability $\left(1_{\mathrm{x}}\right)$ of the life and fertility tables, the net reproductive rate $\left(\mathrm{R}_{0}\right)$, the generation time $(T)$, the intrinsic growth rate $\left(r_{m}\right)$, finite increase rate $(\lambda)$ and the population doubling time (Dt) (Krebs, 1994) were calculated, where $\mathrm{R}_{0}=\sum\left(\mathrm{l}_{\mathrm{x}} \mathrm{m}_{\mathrm{x}}\right) ; \mathrm{T}=\sum\left(\mathrm{xl}_{\mathrm{x}} \mathrm{m}_{\mathrm{x}}\right) / \sum\left(\mathrm{l}_{\mathrm{x}} \mathrm{m}_{\mathrm{x}}\right)$; $\mathrm{r}_{\mathrm{m}}=\ln \mathrm{R}_{0} / \mathrm{T} ; \lambda=\mathrm{e}^{\mathrm{rm}} ;$ and $\mathrm{Dt}=\ln (2) / \mathrm{r}_{\mathrm{m}}$.

\subsection{Data analysis}

The data of biological parameters were subjected to Taylor's Power Law (Taylor, 1984) for homogenization of the means and reduction of the variances to indicate 
the best data transformation using $\arcsin \sqrt{x / 100}$ for the parameters sex ratio and egg viability. Analysis of variance (SAS INSTITUTE, 2000) was used and the means of the Brassicacea treatments were compared by Tukey's test at $5 \%$ significance.

The population parameters of the fertility life table were estimated (Maia et al., 2000), using SAS (SAS INSTITUTE, 2000) software, based on the jackknife method for estimating the parameters, confidence intervals, and to allow treatment comparisons.

\section{Results}

The duration of the second $\left(\mathrm{F}_{2: 15}=0.26 ; \mathrm{P}>0.05\right)$, third $\left(\mathrm{F}_{2: 15}=3.64 ; \mathrm{P}>0.05\right)$, fourth $\left(\mathrm{F}_{2: 15}=2.13 ; \mathrm{P}>0.05\right)$, and fifth $\left(\mathrm{F}_{2 ; 15}=0.43 ; \mathrm{P}>0.05\right)$ instars and the nymph period $\left(\mathrm{F}_{2,15}=0.38 ; \mathrm{P}>0.05\right)$ of $P$. nigrispinus fed on P. xylostella larvae on different Brassicaceae were similar. However, nymph viability $\left(\mathrm{F}_{2 ; 15}=4.09 ; \mathrm{P}<0.05\right)$ of this predator on broccoli $(80.00 \%)$ was longer then on kale $(56.67 \%)$ and cabbage $(61.67 \%)$, whereas nymph prey consumption $\left(\mathrm{F}_{2 ; 15}=1.75\right)$ was similar between treatments, 29.18 (cabbage) to 41.75 (kale) P. xylostella larvae per nymph of the predator (Table 1).
The mean weight of fifth-instar nymphs $\left(\mathrm{F}_{2 ; 15}=0.68\right.$; $\mathrm{P}>0.05)$ and newly emerged females $\left(\mathrm{F}_{2: 15}=0.45 ; \mathrm{P}>0.05\right)$ as well as the sex ratio $\left(\mathrm{F}_{2: 10}=1.04 ; \mathrm{P}>0.05\right)$ of insects were similar in all treatments. However, newly emerged males $\left(\mathrm{F}_{2: 27}=4.23 ; \mathrm{P}<0.05\right)$ on cabbage and broccoli had higher mean weight. The mean weight of fifth- instar nymphs was similar between treatments, varying from $17.71 \mathrm{mg}$ (kales and cabbage) to $19.70 \mathrm{mg}$ (broccoli). The weight of newly emerged predator males was higher on kales $(33.49 \mathrm{mg})$ and broccoli $(28.61 \mathrm{mg})$ than on cabbage $(23.58 \mathrm{mg})$, while no differences were observed in the mean weight of newly emerged females, $39.02 \mathrm{mg}$ (cabbage) to $43.35 \mathrm{mg}$ (broccoli). The sex ratio of this predator was similar in the three treatments, 0.44 (broccoli) to 0.68 (cabbage) (Table 2).

The parameters eggs per female $\left(\mathrm{F}_{2 ; 27}=6.41 ; \mathrm{P}<0.01\right)$, number of ovipositions $\left(\mathrm{F}_{2,27}=6.59 ; \mathrm{P}<0.01\right)$ and eggs per egg mass $\left(\mathrm{F}_{2 ; 27}=3.56 ; \mathrm{P}<0.05\right)$ differed between treatments with higher for $P$. nigrispinus nymphs fed on broccoli. The incubation period $\left(\mathrm{F}_{2: 27}=0.70 ; \mathrm{P}>0.05\right)$ and viability $\left(\mathrm{F}_{2: 27}=1.85 ; \mathrm{P}>0.05\right)$ were not different between treatments (Table 3 ).

The number of eggs per female of this predator $\left(\mathrm{F}_{2: 27}=3.56\right.$; $\mathrm{P}<0.05$ ) reared on broccoli was 2.38 folds higher than on kale and 2.44 folds higher than on cabbage, indicating that

Table 1. Duration of nymph stages (days), nymph period (days), nymph survival (\%), and prey consumption (mean \pm SE) by Podisus nigrispinus (Heteroptera: Pentatomidae) nymphs fed on Plutella xylostella (Lepidoptera: Plutellidae) larvae with leaves of three Brassicacea cultivars. Jaboticabal, São Paulo, Brazil, 2012.

\begin{tabular}{|c|c|c|c|c|c|c|c|}
\hline \multirow{2}{*}{ Treatament } & \multicolumn{4}{|c|}{ Nymph Stages } & \multirow{2}{*}{$\begin{array}{c}\text { Nymphal } \\
\text { Period }\end{array}$} & \multirow{2}{*}{$\begin{array}{l}\text { Nymph } \\
\text { Survival }\end{array}$} & \multirow{2}{*}{$\begin{array}{c}\text { Prey } \\
\text { Consumption }\end{array}$} \\
\hline & $2^{\circ}$ & $3^{\circ}$ & $4^{0}$ & $5^{\circ}$ & & & \\
\hline Kales & $4.14 \pm 0.22 \mathrm{a}$ & $2.73 \pm 0.98 \mathrm{a}$ & $4.12 \pm 1.10 \mathrm{a}$ & $5.90 \pm 1.12 \mathrm{a}$ & $18.90 \pm 1.65 \mathrm{a}$ & $56.67 \pm 18.05 \mathrm{~b}$ & $41.75 \pm 13.72 \mathrm{a}$ \\
\hline Cabbage & $4.10 \pm 0.75 \mathrm{a}$ & $4.18 \pm 1.47 \mathrm{a}$ & $3.10 \pm 0.46 \mathrm{a}$ & $5.36 \pm 1.01 \mathrm{a}$ & $18.74 \pm 1.42 \mathrm{a}$ & $61.67 \pm 14.41 \mathrm{~b}$ & $29.18 \pm 8.04 \mathrm{a}$ \\
\hline Broccolis & $3.95 \pm 0.47 \mathrm{a}$ & $2.57 \pm 0.54 \mathrm{a}$ & $3.87 \pm 0.61 \mathrm{a}$ & $5.85 \pm 0.73 \mathrm{a}$ & $18.23 \pm 1.00 \mathrm{a}$ & $80.00 \pm 12.65 \mathrm{a}$ & $31.55 \pm 9.49 \mathrm{a}$ \\
\hline
\end{tabular}

Means followed by the same letter per column did not differ by Tukey's test $(\mathrm{P}<0.05)$.

Table 2. Weight of fifth instar nymphs and of newly emerged males and females (mg) and sex ratio (mean $\pm \mathrm{SE}$ ) of Podisus nigrispinus (Heteroptera: Pentatomidae) fed on Plutella xylostella (Lepidoptera: Plutellidae) larvae with leaves of three Brassicacea cultivars. Jaboticabal, São Paulo, Brazil, 2012.

\begin{tabular}{lcccc}
\hline \multirow{2}{*}{ Treatament } & \multicolumn{3}{c}{ Weight } & \multirow{2}{*}{ Sex Ratio $^{\mathbf{1}}$} \\
\cline { 2 - 4 } & $\mathbf{5}^{\text {th }}$-instar & Males & Females & \\
\hline Kales & $17.71 \pm 2.94 \mathrm{a}$ & $33.49 \pm 7.58 \mathrm{a}$ & $41.49 \pm 8.50 \mathrm{a}$ & $0.52 \pm 0.24 \mathrm{a}$ \\
Cabbage & $17.71 \pm 4.57 \mathrm{a}$ & $23.58 \pm 9.65 \mathrm{~b}$ & $39.02 \pm 13.88 \mathrm{a}$ & $0.68 \pm 0.22 \mathrm{a}$ \\
Broccolis & $19.70 \pm 4.03 \mathrm{a}$ & $28.61 \pm 4.86 \mathrm{ab}$ & $43.35 \pm 7.05 \mathrm{a}$ & $0.44 \pm 0.31 \mathrm{a}$ \\
\hline
\end{tabular}

Means followed by the same letter per column did not differ by Tukey's test $(\mathrm{P}<0.05)$. ${ }^{1}$ Original data. Data were transformed to $\arcsin \sqrt{x / 100}$ for statistical analysis (Taylor, 1984).

Table 3. Number of eggs per female, number of egg mass per female, egg incubation period (days), egg viability (\%), and number of eggs per egg mass (mean $\pm \mathrm{SE}$ ) of Podisus nigrispinus (Heteroptera: Pentatomidae) fed on Plutella xylostella (Lepidoptera: Plutellidae) larvae with leaves of three Brassicacea cultivars. Jaboticabal, São Paulo, Brazil, 2012.

\begin{tabular}{lccccc}
\hline \multicolumn{1}{c}{ Treatament } & Eggs/Female & Clutches & $\begin{array}{c}\text { Incubation } \\
\text { Period }\end{array}$ & Viability $^{\mathbf{1}}$ & Eggs/Clutch $^{\text {E }}$ \\
\hline Kales & $196.10 \pm 57.53 \mathrm{~b}$ & $5.80 \pm 1.77 \mathrm{~b}$ & $5.12 \pm 0.80 \mathrm{a}$ & $55.60 \pm 11.42 \mathrm{a}$ & $23.12 \pm 0.54 \mathrm{~b}$ \\
Cabbage & $191.90 \pm 38.10 \mathrm{~b}$ & $2.90 \pm 2.46 \mathrm{~b}$ & $5.05 \pm 0.73 \mathrm{a}$ & $63.79 \pm 13.03 \mathrm{a}$ & $17.74 \pm 0.04 \mathrm{~b}$ \\
Broccolis & $467.90 \pm 87.12 \mathrm{a}$ & $13.10 \pm 4.96 \mathrm{a}$ & $5.34 \pm 0.86 \mathrm{a}$ & $59.69 \pm 9.75 \mathrm{a}$ & $35.76 \pm 0.89 \mathrm{a}$ \\
\hline
\end{tabular}

Means followed by the same letter per column did not differ by Tukey's test $(\mathrm{P}<0.05)$. ${ }^{1}$ Original data. Data were transformed to $\arcsin \sqrt{x / 100}$ for statistical analysis (Taylor 1984). 
broccoli provided better conditions for oviposition of P. nigrispinus. The number of ovipositions $\left(\mathrm{F}_{2 ; 27}=6.59\right.$; $\mathrm{P}<0.01)$ was higher on broccoli (13.10) than on kale (5.80) and cabbage (2.90). The number of eggs per egg mass was higher on broccoli (35.76) compared to kale (23.12) and cabbage (17.74). However, the egg viability $\left(\mathrm{F}_{2 ; 27}=1.85 ; \mathrm{P}>0.05\right)$ was similar between treatments, i.e., $55.60 \%$ (kale), $59.69 \%$ (broccoli) and $63.79 \%$ (cabbage). This pattern was similar to that of the incubation period $\left(\mathrm{F}_{2 ; 27}=0.70 ; \mathrm{P}>0.05\right), 5.05$ days (cabbage), 5.12 days (kale) and 5.34 days (broccoli) (Table 3).

The consumption of adult predators $\left(\mathrm{F}_{2 ; 29}=8.19 ; \mathrm{P}<0.01\right)$, male $\left(\mathrm{F}_{2 ; 29}=15.80 ; \mathrm{P}<0.01\right)$ and female $\left(\mathrm{F}_{2 ; 29}=18.42\right.$; $\mathrm{P}<0.01)$ longevities differed, with higher values of the predator with broccoli (Table 4).

The consumption of $P$. nigrispinus adults on broccoli t (306.21 larvae) was higher than with kale (182.21 larvae) and cabbage (172.50 larvae). Female longevity was longer on broccoli (37.86 days) than on kale (17.43 days) and cabbage (23.00 days). Male longevity was highest on broccoli (42.29 days) than on kale (25.00 days), that was higher than on cabbage (8.00 days) (Table 4).

The Brassicaceae affected population parameters of the life table of $P$. nigrispinus. The net reproductive rate $\left(\mathrm{R}_{0}\right)$ (75.3 females/female) and generation time $(\mathrm{T})$ (37.6 days) of this predator were higher with broccoli. The intrinsic population increase rate $\left(\mathrm{r}_{\mathrm{m}}\right)$, finite population increase rate $(\lambda)$ and the time required for population doubling (TD) were similar between the Brassicacea cultivars (Table 5).

\section{Discussion}

Development and reproduction of $P$. nigrispinus varied with Brassicacea cultivar. The plant material can have positive effects on the development of predatory stinkbugs even under adverse situations (Lemos et al., 2001). Thus, the reproduction and population growth rates of this insect are high when fed on prey and plants (Guedes et al., 2007).

Podisus nigrispinus feeding on prey with broccoli had improved biological parameters what agrees with that found with Eucalyptus urophylla with reduced nymph mortality and increased adult longevity and the number of eggs per female and $P$. nigrispinus nymphs. This indicates that this predator can be fed with both prey and Eucalyptus in the field as well as in the laboratory (Holtz et al., 2011).

Results obtained in the present study could be explained because plant material can compensate a possible low nutritional quality of the prey by supplying water and nutrients that would increase weight, reproduction and longevity of these predators (Guedes et al., 2007). The development and reproduction of Supputius cincticeps (Stal) and Brontocoris tabidus Signoret (Hemiptera: Pentatomidae) was also improved when fed on T. molitor pupae on eucalyptus plants with exclusively prey (Zanuncio et al., 2000).

The duration of nymph period with kale (18.90), cabbage (18.74) and broccoli (18.23) were similar to that reported for the nymph period of $P$. nigrispinus fed only on Spodoptera frugiperda (J.E. Smith) (Lepidoptera: Noctuidae) and on pupae of T. molitor, respectively, 21.6 and 20.4 days (Oliveira et al., 2004b).

The weight of fifth-instar nymphs and of newly emerged males and females in the three treatments were

Table 4. Consumption of Plutella xylostella (Lepidoptera: Plutellidae) larvae and longevity (days) of Podisus nigrispinus (Heteroptera: Pentatomidae) adults and longevity (days) of P. nigrispinus males and females (mean $\pm \mathrm{S}$ E) fed on P. xylostella larvae with leaves of three Brassicacea cultivars. Jaboticabal, São Paulo, Brazil, 2012.

\begin{tabular}{lcrc}
\hline \multirow{2}{*}{ Treatament } & \multirow{2}{*}{ Consumption } & \multicolumn{2}{c}{ Longevity (days) } \\
\cline { 3 - 4 } & & \multicolumn{1}{c}{ Male } & Female \\
\hline Kales & $182.21 \pm 21.29 \mathrm{~b}$ & $25.00 \pm 4.41 \mathrm{~b}$ & $17.43 \pm 1.81 \mathrm{~b}$ \\
Cabbage & $172.50 \pm 30.34 \mathrm{~b}$ & $8.00 \pm 4.31 \mathrm{c}$ & $23.00 \pm 2.94 \mathrm{~b}$ \\
Broccolis & $306.21 \pm 31.09 \mathrm{a}$ & $42.29 \pm 6.90 \mathrm{a}$ & $37.86 \pm 1.89 \mathrm{a}$ \\
\hline
\end{tabular}

Means followed by the same letter per column did not differ by Tukey's test $(\mathrm{P}<0.05)$.

Table 5. Fertility life table parameters (mean \pm SE) of Podisus nigrispinus (Heteroptera: Pentatomidae) fed on Plutella xylostella (Lepidoptera: Plutellidae) larvae with leaves of three Brassicacea cultivars. Jaboticabal, São Paulo, Brazil, 2012.

\begin{tabular}{lccc}
\hline \multicolumn{1}{c}{ Parâmetro $^{1}$} & Kales & Cabbage & Broccolis \\
\hline $\mathrm{R}_{0}$ (female/female) & $57.1 \pm 14.08 \mathrm{~b}^{2}$ & $47.6 \pm 15.96 \mathrm{~b}$ & $75.3 \pm 13.90 \mathrm{a}$ \\
$\mathrm{T}$ (days) & $29.1 \pm 6.89 \mathrm{~b}$ & $28.8 \pm 7.49 \mathrm{~b}$ & $37.6 \pm 7.23 \mathrm{a}$ \\
$\mathrm{r}_{\mathrm{m}}$ (fềmeas/fêmea*dia) & $0.139 \pm 0.0406 \mathrm{a}$ & $0.139 \pm 0.0272 \mathrm{a}$ & $0.115 \pm 0.0159 \mathrm{a}$ \\
$\Lambda$ (females/females/day) & $1.149 \pm 0.0463 \mathrm{a}$ & $1.149 \pm 0.0312 \mathrm{a}$ & $1.122 \pm 0.0179 \mathrm{a}$ \\
$\mathrm{TD}$ (days) & $4.9 \pm 1.62 \mathrm{a}$ & $4.9 \pm 0.98 \mathrm{a}$ & $5.9 \pm 0.79 \mathrm{a}$
\end{tabular}

${ }^{1} R_{0}=\sum\left(1_{x} \mathrm{~m}_{x}\right)$, for the number of eggs per female per generation, where $1_{x}=$ proportion of mated females alive at age $x$; $\mathrm{m}_{x}=$ age-specific fecundity rates multiplied by the sex ratio $(0.52,0.68$, and 0.43 sex ratio on kale, cabbage, and broccoli, respectively); $T=\sum\left(x \mathrm{l}_{x} \mathrm{~m}_{x}\right) / \sum\left(1_{x} \mathrm{~m}_{x}\right) ; r_{\mathrm{m}}=\ln R_{0} / T$; and $\lambda=\mathrm{e}^{\mathrm{rm}} ;{ }^{2}$ Means $\pm \mathrm{IC}$ followed by the same letter per row do not differ from each other by the " $\mathrm{t}$ " paired comparison test by the Jackknife method. 
lower than that of fifth-instar nymphs and males and females P. nigrispinus fed on Thyrinteina arnobia (Stoll, 1792) (Lepidoptera: Geometridae) with guava leaves (Oliveira et al., 2011). The higher weight of females than males was due to the biomass accumulated by females from the fifth-instar stage, necessary for reproduction. The weight gain of the females was also related to the ovary development and egg formation (Oliveira et al., 1999; Oliveira et al., 2002).

The mean number of eggs per P. nigrispinus female fed with P. xylostella and broccoli (467.90) was higher than with T. arnobia larvae on guava trees (314.90) (Oliveira et al., 2011), Alabama argillacea (Hüebner, 1818) (Lepidoptera: Noctuidae) on cotton (348.10) (Oliveira et al., 2002), and with T. molitor (296.66; 325.00) (Oliveira et al., 2004b; Espindula et al., 2006), Diatraea saccharalis (Fabricius, 1794) (Lepidoptera: Pyralidae) (97.12) (Vacari et al., 2007) and T. arnobia (57.00) on Eucalyptus (Holtz et al., 2006; Holtz et al., 2007). This high number of eggs suggests that the prey P. xylostella and broccoli leaf may have higher nutritional values for the predator $P$. nigrispinus.

In the field, plant-derived substances can be an alternative or complementing the diet of predatory bugs (Crum et al., 1998), allowing them to maintain their longevity (Valicente and O'Neil, 1995; Zanuncio et al., 2004). The use of plants as dietary supplement may or may not lead to a better establishment of predatory bug populations, depending on the composition of the agroecosystems (Oliveira et al., 2002). Food source may affect the development and reproduction of these species since the nutritional value of plants depends on their species and natural enemies (Wackers, 2004). The greater viability of nymphs on broccoli leaves indicates that this Brassicacea has a positive influence on the rearing of $P$. nigrispinus.

The use of predatory bugs in biological control programs can reduce the use of insecticides and the environmental impacts they cause. The mass rearing of insects is important to provide natural enemies for research and commercial purposes. The use of $P$. xylostella and broccoli leaves has proved promising in rearing the predator with longer longevity and better reproductive parameters.

\section{Acknowledgements}

The authors gratefully acknowledge the scholarships granted by the Coordenação de Aperfeiçoamento de Pessoal de Nível Superior (CAPES) and the Conselho Nacional de Desenvolvimento Científico e Tecnológico $(\mathrm{CNPq})$ and thank the Universidade Estadual Paulista for the infrastructure.

\section{References}

AZEVEDO, D.O., ZANUNCIO, J.C., ZANUNCIO JUNIOR, J.S., MARTINS, G.F., MARQUES-SILVA, S., SOSSAI, M.F. and SERRÃO, J.E., 2007. Biochemical and morphological aspects of salivary glands of the predator Brontocoris tabidus (Heteroptera: Pentatomidae). Brazilian Archives of Biology and Technology, vol. 50, no. 3, pp. 469-477. http://dx.doi.org/10.1590/S151689132007000300013.

BIRCH, L.C., 1948. The intrinsic rate of natural increase of an insect population. Journal of Animal Ecology, vol. 17, no. 1, pp. 15-26. http://dx.doi.org/10.2307/1605.

CHAPMAN, R.F., 1998. Reproductive system: female. In: R.F. CHAPMAN. The insects: structure and function. Cambridge: Cambridge University, pp. 295-324.

COLL, M. and GUERSHON, M., 2002. Omnivory in terrestrial arthropods: mixing plant and prey diet. Annual Review of Entomology, vol. 47, no. 1, pp. 267-297. PMid:11729076. http:// dx.doi.org/10.1146/annurev.ento.47.091201.145209.

CRUM, D.A., WEISER, L.A. and STAMP, N.E., 1998. Effects of prey scarcity and plant material as a dietary supplement on an insect predator. Oikos, vol. 83, no. 3, pp. 549-557. http://dx.doi. org/10.2307/3546775.

DE CLERCQ, P. and DEGHEELE, D., 1992. Development and survival of Podisus maculiventris (Say) and Podisus sagitta (Fab.) (Heteroptera, Pentatomidae) at various constant temperatures. Canadian Entomologist, vol. 124, no. 01, pp. 125-133. http:// dx.doi.org/10.4039/Ent124125-1.

DE CLERCQ, P., 2000. Predaceous stink bugs (Pentatomidae, Asopinae). In: C.W. SCHAEFER, A.R. PANIZZI. Heteroptera of economic importance. Cambridge: Cambridge University, pp. 737-789.

DE CLERCQ, P., MERLEVEDE, F. and TIRRY, L., 1998. Unnatural prey and diets for rearing Podisus maculiventris (Heteroptera, Pentatomidae). Biological Control, vol. 12, no. 2, pp. 137-142. http://dx.doi.org/10.1006/bcon.1998.0611.

ESPINDULA, M.C., OLIVEIRA, H.N., CAMPANHARO, M., PASTORI, P.L. and MAGEVSKI, G.C., 2006. Influência da massa corporal sobre características reprodutivas e longevidade de fêmeas de Podisus nigrispinus (Dallas) (Heteroptera: Pentatomidae). Idesia, vol. 24, pp. 19-25.

EUBANKS, M. and DENNO, R.F., 2000. Host plants mediate omnivore-herbivore interactions and influence prey suppression. Ecology, vol. 81, pp. 936-947.

FERNANDES, L.G., CARVALHO, C.F., BUENO, V.H.P. and DINIZ, L.C., 1996. Aspectos biológicos de Brontocoris tabidus Signoret, 1852 e Podisus nigrispinus (Dallas, 1851) (Hemiptera: Pentatomidae). Cerne, vol. 2, no. 1, pp. 1-10.

GILLESPIE, D.R. and MCGREGOR, R.R., 2000. The functions of plant feeding in the omnivorous predator Dicyhus hesperus: water places limits on predation. Ecological Entomology, vol. 25, no. 4, pp. 380-386. http://dx.doi.org/10.1046/j.1365-2311.2000.00285.x.

GUEDES, B.A.M., ZANUNCIO, J.C., RAMALHO, F.S. and SERRAO, J.E., 2007. Midgut morphology and enzymes of the obligate zoophytophagous stinkbug Brontocoris tabidus (Signoret, 1863) (Heteroptera: Pentatomidae). The Pan-Pacific Entomologist, vol. 83, no. 1, pp. 66-74. http://dx.doi.org/10.3956/0031-060383.1.66.

HOLTZ, A.M., ALMEIDA, G.D., FADINI, M.A.M., ZANUNCIO, J.C., ZANUNCIO-JÚNIOR, J.S. and ANDRADE, G.S., 2011. Phytophagy on eucalyptus plants increases the development and reproduction of the predator Podisus nigrispinus (Hemiptera: Pentatomidae). Acta Scientiarum: Agronomy, vol. 33, no. 2, pp. 231-235. 
HOLTZ, A.M., ZANUNCIO, J.C., MARINHO, J.S., PRATISSOLI, D., PALLINI, A. and PEREIRA, C.J., 2006. Características biológicas de adultos de Podisus nigrispinus e Supputius cincticeps (Hemiptera: Pentatomidae) alimentados com Thyrinteina arnobia (Lepidoptera: Geometridae). Idesia, vol. 24, pp. 41-418.

HOLTZ, A.M., ZANUNCIO, J.C., OLIVEIRA, C.L., PRATISSOLI, D., PALLINI, A., MARINHO, J.S. and VIANNA, U.R., 2007. Potencial reprodutivo e de sobrevivência de Podisus nigrispinus Dallas (Heteroptera: Pentatomidae) sobre Thyrinteina arnobia Stoll Lepidoptera: Geometridae) e Tenebrio molitor L. (Coleoptera: Tenebrionidae). Floresta, vol. 37, no. 1, pp. 63-70. http://dx.doi. org/10.5380/rf.v37i1.7842.

KREBS, C.J., 1994. Ecology: the experimental analysis of distribution and abundance. New York: Harper \& Row. 801 p.

LALONDE, R.G., MCGREGOR, R.R., ROITBERGER, B.D. and GILLESPIE, D.R., 1999. Plant-feeding by arthropod predators contributes the stability of predator-prey population dynamics. Oikos, vol. 87, no. 3, pp. 603-609. http://dx.doi.org/10.2307/3546827.

LEMOS, W.P., MEDEIROS, R.S., RAMALHO, F.S. and ZANUNCIO, J.C., 2001. Effects of plant feeding on the development, survival, and reproduction of Podisus nigrispinus (Dallas) (Heteroptera, Pentatomidae). International Journal of Pest Management, vol. 27, no. 2, pp. 89-93. http://dx.doi.org/10.1080/09670870151130499.

LENSKI, R.E., 1984. Food limitation and competition: a field experiment with two Carabus species. Journal of Animal Ecology, vol. 53, no. 1, pp. 203-216. http://dx.doi.org/10.2307/4352.

MAIA, A.H., LUIZ, A.J.B. and CAMPANHOLA, C., 2000. Statistical inference on associated fertility life parameters using Jackknife technique: computational aspects. Journal of Economic Entomology, vol. 93, no. 2, pp. 511-518. PMid:10826207. http:// dx.doi.org/10.1603/0022-0493-93.2.511.

MEDEIROS, R.S., RAMALHO, F.S., LEMOS, W.P. and ZANUNCIO, J.C., 2000. Age-dependent fecundity and life-fertility tables for Podisus nigrispinus (Dallas) (Heteroptera, Pentatomidae). Journal of Applied Entomology, vol. 124, no. 7-8, pp. 319-324. http:// dx.doi.org/10.1046/j.1439-0418.2000.00482.x.

MOLINA-RUGAMA, A.J., ZANUNCIO, J.C., TORRES, J.B., ZANUNCIO, T.V., 1997. Longevidad y fecundidad de Podisus nigrispinus (Heteroptera: Pentatomidae) alimentado com Musca domestica (Diptera: Muscidae) y frijol. Revista de Biologia Tropical $=$ Journal of Tropical Biology, vol. 45, pp. 1125-1130.

MOLINA-RUGAMA, A.J., ZANUNCIO, J.C., PRATISSOLI, D. and CRUZ, I., 1998a. Efeito do intervalo de alimentação na reprodução e na longevidade do predador Podisus nigrispinus (Dallas) (Heteroptera: Pentatomidae). Anais da Sociedade Entomológica do Brasil, vol. 27, no. 1, pp. 77-84. http://dx.doi. org/10.1590/S0301-80591998000100010.

MOLINA-RUGAMA, A.J., ZANUNCIO, J.C., ZANUNCIO, T.V. and OLIVEIRA, M.L.R., 1998b. Reproductive strategy of Podisus rostralis (Stal) (Heteroptera: Pentatomidae) females under different feeding intervals. Biocontrol Science and Technology, vol. 8, no. 4, pp. 583-588. http://dx.doi.org/10.1080/09583159830090.

MOURÃO, S.A., ZANUNCIO, J.C., MOLINA-RUGAMA, A.J., VILELA, E.F. and LACERDA, M.C., 2003. Efeito da escassez de presa na sobrevivência e reprodução do predador Supputius cincticeps (Stal) (Heteroptera: Pentatomidae). Neotropical Entomology, vol. 32, no. 3, pp. 469-473. http://dx.doi.org/10.1590/ S1519-566X2003000300014.
NARANJO, S.E. and STIMAC, J.L., 1985. Development, survival, and reproduction of Geocoris punctipes (Hemiptera, Lygaeidae): effects of plant feeding on soybean and associated weeds. Environmental Entomology, vol. 14, no. 4, pp. 523-530. http://dx.doi.org/10.1093/ee/14.4.523.

NARANJO, S.E. and STIMAC, J.L., 1987. Plant influences on predation and oviposition by Geocoris punctipes (Hemiptera, Lygaeidae) in soybeans. Environmental Entomology, vol. 16, no. 1, pp. 182-189. http://dx.doi.org/10.1093/ee/16.1.182.

OLIVEIRA, H.N., ZANUNCIO, J.C., SOSSAI, M.F. and PRATISSOLI, D., 1999. Body weight increment of Podisus nigrispinus (Stal) (Heteroptera: Pentatomidae), fed on Tenebrio molitor L. (Coleoptera: Tenebrionidae) or Musca domestica L. (Diptera: Muscidae). Brenesia, vol. 51, pp. 77-83

OLIVEIRA, H.N., ESPINDULA, M.C., PRATISSOLI, D. and PEDRUZZI, E.P., 2004a. Ganho de peso e comportamento de oviposição de Podisus nigrispinus utilizando lagartas de Spodoptera frugiperda e larvas de Tenebrio molitor como presas. Ciência Rural, vol. 34, no. 6, pp. 1945-1948. http://dx.doi.org/10.1590/ S0103-84782004000600043.

OLIVEIRA, H.N., PRATISSOLI, D., PEDRUZZI, E.P. and ESPINDULA, M.C., 2004b. Desenvolvimento do predador Podisus nigrispinus alimentado com Spodoptera frugiperda e Tenebrio molitor. Pesquisa Agropecuaria Brasileira, vol. 39, no. 10, pp. 947-951. http://dx.doi.org/10.1590/S0100-204X2004001000001.

OLIVEIRA, H.N., ESPINDULA, M.C., DUARTE, M.M., PEREIRA, F.F. and ZANUNCIO, J.C., 2011. Development and reproduction of Podisus nigrispinus (Hemiptera: Pentatomidae) fed with Thyrinteina arnobia (Lepidoptera: Geometridae) reared on guava leaves. Brazilian Archives of Biology and Technology, vol. 54, no. 3, pp. 429-434. http://dx.doi.org/10.1590/S151689132011000300001

OLIVEIRA, J.E.M., TORRES, J.B., CARRANO-MOREIRA, A.F. and BARROS, R., 2002. Efeito das plantas do algodoeiro e do tomateiro, como complemento alimentar, no desenvolvimento e na reprodução do predador Podisus nigrispinus (Dallas) (Heteroptera: Pentatomidae). Neotropical Entomology, vol. 31, no. 1, pp. 101108. http://dx.doi.org/10.1590/S1519-566X2002000100014.

PRICE, P.W., 1984. Insect ecology. 2nd ed. New York: John Willey. 607 p.

RUBERSON, J.R., TAUBER, J.M. and TAUBER, C.A., 1986. Plant feeding by Podisus maculiventris (Heteroptera, Pentatomidae): effect on survival, development, and pre oviposition period. Environmental Entomology, vol. 15, no. 4, pp. 894-897. http:// dx.doi.org/10.1093/ee/15.4.894.

SAAVEDRA, J.L.D., ZANUNCIO, J.C., ZANUNCIO, T.V. and GUEDES, R.N., 1997. Prey capture ability of Podisus nigrispinus (Dallas) (Heteroptera: Pentatomidae) reared for successive generations on meridic diets. Journal of Applied Entomology, vol. 12, no. 1-5, pp. 327-330. http://dx.doi.org/10.1111/j.1439-0418.1997.tb01414.x.

SAS INSTITUTE, 2000. SAS/C OnlineDocTM: version 8. Cary: SAS Institute, Inc.

SILVEIRA NETO, S., NAKANO, O., BALDIN, D. and VILLANOVA, N.A., 1976. Manual de ecologia dos insetos. São Paulo: Agronômica Ceres. 419 p

SINIA, A., ROITBERG, B., MCGREGOR, R.R. and GILLESPIE, D.R., 2004. Prey feeding increases water stress in the omnivorous predator Dicyphus hesperus. Entomologia Experimentalis et 
Applicata, vol. 110, no. 3, pp. 243-248. http://dx.doi.org/10.1111/ j.0013-8703.2004.00145.x.

TAYLOR, L.R., 1984. Accessing and interpreting the spatial distributions of insect populations. Annual Review of Entomology, vol. 29, no. 1, pp. 321-357. http://dx.doi.org/10.1146/annurev. en.29.010184.001541.

THOMAS, D.B., 1992. Taxonomic synopsis of the Asopinae Pentatomidae (Heteroptera) of the Western Hemisphere. Lanham: Entomological Society of America. 156 p.

VACARI, A.M., OTUKA, A.K. and BORTOLI, S.A., 2007. Desenvolvimento de Podisus nigrispinus (Dallas, 1851) (Hemiptera: Pentatomidae) alimentado com lagartas de Diatraea saccharalis (Fabricius, 1794) (Lepidoptera: Crambidae). Arquivos do Instituto Biologico, vol. 74, pp. 259-265.

VALICENTE, F.H. and O'NEIL, R.J., 1993. Effects of two host plants on selected life history characteristics of Podisus maculiventris (Say) (Heteroptera, Pentatomidae). 1 - Without access to prey. Environmental Entomology, vol. 23, pp. 1254-1259.

VALICENTE, F.H. and O’NEIL, R.J., 1995. Effect of host plants and feeding regimes on selected life history characteristics of Podisus maculiventris (Say) (Heteroptera: Pentatomidae). Biological Control, vol. 5, no. 3, pp. 449-461. http://dx.doi. org/10.1006/bcon.1995.1054.

WACKERS, F.L., 2004. A comparison of nectar and honeydew sugars with respect to their utilization by the hymenopteran parasitoid Cotesia glomerata. Journal of Insect Physiology, vol. 47, no. 9, pp. 1077-1084. PMid:11472770. http://dx.doi. org/10.1016/S0022-1910(01)00088-9.
ZANUNCIO, J.C., GUEDES, R.N.C., OLIVEIRA, H.N. and ZANUNCIO, T.V., 2002. Uma década de estudos com percevejos predadores: conquistas e desafios. In: J.R.P. PARRA, P.S.M. BOTELHO, B.S. CORREAA-FERREIRA, J.M.S. BENTO. Controle biológico no Brasil: parasitoide e predadores. São Paulo: Manole, pp. 405-505.

ZANUNCIO, J.C., LACERDA, M.C., ZANUNCIO JÚNIOR, J.C., ZANUNCIO, T.V., SILVA, M.C. and ESPINDULA, M.C., 2004. Fertility and life table and rate of population growth of the predator Supputius cincticeps (Heteroptera: Pentatomidae) on plant of Eucalyptus cloeziana in the field. Annals of Applied Biology, vol. 144, no. 3, pp. 357-361. http://dx.doi.org/10.1111/j.1744-7348.2004. tb00351.x. ZANUNCIO, J.C., SAAVEDRA, J.L.D., OLIVEIRA, H.N., DEGHEELE, D. and DE CLERCQ, P., 1996a. Development of the predatory stinkbug Brontocoris tabidus (Signoret) (Heteroptera: Pentatomidae) on different proportions of an artificial diet and pupae of Tenebrio molitor L. (Coleoptera: Tenebrionidae). Biocontrol Science and Technology, vol. 6, no. 4, pp. 619-625. http://dx.doi.org/10.1080/09583159631253.

ZANUNCIO, T.V., ZANUNCIO, J.C., SAAVEDRA, J.L.D. and LOPES, E.D., 1996b. Desenvolvimento de Podisus nigrispinus (Dallas) (Heteroptera: Pentatomidae) com Zophobas confusa Gebien (Coleoptera: Tenebrionidae) comparado a duas outras presas alternativas. Revista Brasileira de Zoologia, vol. 13, no. 1, pp. 159-164. http://dx.doi.org/10.1590/S0101-81751996000100016.

ZANUNCIO, J.C., ZANUNCIO, T.V., GUEDES, R.N.C. and RAMALHO, F.S., 2000. Effect of feeding on three Eucalyptus species on the development of Brontocoris tabidus (Heteroptera: Pentatomidae) fed with Tenebrio molitor (Coleoptera: Tenebrionidae). Biocontrol Science and Technology, vol. 10, pp. 443-450. http:// dx.doi.org/10.1080/09583150050115025. 